\title{
A Flipped Writing Classroom: Effects on EFL Learners' Argumentative Essays
}

\author{
Fatemeh Soltanpour ${ }^{1 *}$, Mohammadreza Valizadeh ${ }^{2}$ \\ ${ }^{1}$ English Department, Kar Higher Education Institute PO box 1571, Qazvin, Iran \\ ${ }^{2}$ English Department, Faculty of Foreign Languages, Gazi University, PO Box 06500, Ankara, Turkey
}

Corresponding Author: Fatemeh Soltanpour, E-mail: fatemeh.soltanpour@gmail.com

\section{ARTICLE INFO}

Article history

Received: November 15, 2017

Accepted: December 26, 2017

Published: February 28, 2018

Volume: 9 Issue: 1

Advance access: January 2018

Conflicts of interest: None

Funding: None

\section{Key words:}

Flipped Writing Classroom,

EFL Learner Active Engagement,

Teacher-learner Interaction/

Negotiation,

Argumentative Essay

\begin{abstract}
According to the literature, flipped teaching is a relatively new pedagogical approach in which the typical activities of classroom lectures followed by homework in common teaching practice are reversed in order, and most often integrated or supplemented with some types of instructional materials, such as instructional videos or PowerPoint files. This experimental study, using a pre-test-treatment-posttest-delayed posttest design, was aimed at investigating the effect of flipped instruction on Iranian EFL learners' quality of argumentative essays. The participants were 55 students, who were assigned to two groups: the flipped classroom (FC) and the traditional classroom (TC). Each group received 3 sessions of treatment. First, whether there was any significant difference between the FC and TC in the overall quality of the essays was investigated. The FC group significantly outperformed the TC one. Then, whether the difference between the groups varied over time was explored, and it was revealed that the FC was still significantly superior over the TC. Next, whether there would be any significant change in the FC in the long run was examined, and no significant change was seen. The promising results found in FC group can be attributed to not only the flipped instruction but also the process of actively engaging the learners in their learning in addition to incorporating different techniques, such as the video screencasting, collaborative writing, as well as in-class teacher-learner interaction and negotiation because it is argued that the crucial point in flipped instruction is how teachers best use in-class-time with students.
\end{abstract}

\section{INTRODUCTION}

Writing skill is a complex process because it requires the skillful coordination of both cognitive and linguistic processes and resources (Hayes, 1996; Kellogg, 1996); focusing on higher level skills of planning and organizing (i.e. generating and organizing ideas) as well as lower level skills of spelling, punctuation and word choice can be a daunting task (Richards \& Renandya, 2002). As a result, teaching second language (henceforth, L2) writing skill is not only very important but also challenging for L2 writing instructors (Farah, 2014).

In addition, individual differences (IDs) are known as the "consistent predictors of L2 learning success" (Dörnyei, 2005 , p. 6) and it is expected that learners with different cognitive abilities "execute and orchestrate these processes with varying degrees of efficiency and differ in how they learn to write in another language" (Kormos, 2012, p. 390). Differences in learners' learning styles can also either support or inhibit the learners' intentional cognition and active engagement (Katayama, 2007).

Considering the mentioned issues, the researchers in the current study who were seeking for an effective technique for L2 writing instruction noticed the 'flipped learning approach' and decided to investigate its effectiveness with some Iranian EFL learners. Based on the literature, to resolve the students' writing problems posed by their different needs as the result of their different learning styles, flipped classrooms can be run to facilitate students with different phases of learning and to encourage more student engagement. Flipped teaching, as "a relatively new instructional method" (Ekmekci, 2017, p. 152), is a pedagogical approach in which the typical activities of classroom lectures followed by homework in common teaching practice are reversed in order, and often integrated or supplemented with instructional videos (Ekmekci, 2017; Tucker, 2012).

It is stated that the flipped classroom "serves the principles of personalized-differentiated learning, student-centered instruction, and constructivism." (Basal, 2015, p. 29) It is personalized due to the fact that every individual student views/reviews material and learns at their own pace and according to their own needs (Basal, 2015; Egbert, Herman, \& Lee, 2015; Muldrow, 2013). It is student-centered because the students are highly active and mainly engaged in class activities (Baepler, Walker, \& Driessen, 2014; Basal, 2015; Bishop \& Verleger, 2013; Davies, Dean, \& Ball, 2013; O'Flaherty \& Phillips, 2015), whereas the teacher's role changes to a guide, facilitator and organizer (Basal, 2015; Bishop \& Verleger, 2013). The students take responsibility 
for their own learning (Basal, 2015). Teachers can structure class time to optimize their attention to each individual student (Ekmekci, 2017; Muldrow, 2013) and carefully notice the students' learning and understanding of information (Johnson \& Renner, 2012; Roehl, Reddy, \& Shannon, 2013). Additionally, the class time can incorporate a variety of activities, group work, and interactive discussion (Basal, 2015; Danker, 2015; Egbert et al., 2015; Muldrow, 2013) that may not usually fit into the class activities in traditional classrooms due to time constraints of the curriculum (Egbert et al., 2015; Muldrow, 2013). In light of all the mentioned issues, in a flipped classroom, the students' different needs and learning styles can be addressed (Afrilyasanti, Cahyono, \& Astuti, 2016).

\section{Theoretical Background}

The students are highly active and engaged in class activities, so the principles supporting the flipped instruction approach are rooted in theoretical understandings of active learning (Bonnell \& Eison, 1991; Meyers \& Jones, 1993). Besides, with regard to approaches in language teaching, the flipped instruction follows the learning theories of Communicative Language Teaching (Ahmed, 2016), which is also corroborated by interactional theory and socio-cultural learning theory (Richards \& Rodgers, 2014). In flipped classrooms, the learners cooperate and collaborate as well as interact with the teacher in order to achieve understanding of the lesson, which is consistent with the interactional theory.

A flipped classroom is also supported by Vygotsky's sociocultural theory or social constructivism because, based on Richards and Rodgers' (2014) description of this theory, through flipped instruction, learning takes place through scaffolding, the process of interaction between the people in the classroom, as they do the activities. Learning takes place in a context in which there is interaction among people (students and teachers), instruments (videos, books, etc.) and organized activities.

Moreover, the instructional videos are used in flipped classrooms, which is in fact, an example of Computer or Technology Assisted Language Learning (CALL/TALL), to which the Vygotsky's sociocultural theory can be applied (Warschauer, 2005) due to the fact that based on Vygotsky (1981, as cited in Warschauer, 2005), via mediation or the incorporation of tools or meditational means, the entire flow and structure of mental functions will alter; computer can be an example of those meditational means (Warschauer, 2005). Additionally, the interactive learning environment in the L2 learning, corroborates the social learning aspect of the Vygoskyian's theory (Warschauer, Turbee, \& Roberts, 1996).

In light of the above-mentioned points, the researchers of the current study decided to compare the flipped classroom (FC) with the traditional instruction in a classroom (TC), whose details are going to be explained in the Procedure Section; consequently, this study has addressed the following question:

Is there any significant difference between the $\mathrm{FC}$ group and TC one in the overall quality of their argumentative essays? If so, does the difference between groups vary over time? If one group proves to be superior, will there be any significant change in it in the long term?

\section{REVIEW OF LITERATURE}

As Ekmekci (2017) truly stated, "studies on flipped classroom are limited, but studies on flipped language learning classrooms are much more limited." (p. 155). The following are some of the previous studies relevant to the present one.

Farah (2014) compared the effect of flipped instructional method and traditional one on the writing performance of twelfth grade Emirati female students in a technical high school by a fifteen-week teaching program. She found that the experimental group that experienced flipped instruction significantly outperformed the control group that received traditional instruction.

Leis, Tohei, and Cooke (2015) compared a traditional English composition course with the other using the flipped method with 22 Japanese university students. The results showed that those studying under the flipped method produced a significantly higher number of words in essays. In addition, the participants who received the flipped method resulted in significantly greater improvements in their writing proficiency.

Afrilyasanti et al., (2016) explored the effect of using flipped classroom model on the writing ability of 62 EFL students at an Indonesian secondary school level across their individual differences in learning. The learning group proved to be significantly better than the control group.

Ahmed (2016) investigated the effect of a flipping classroom on writing skill in the EFL context of Saudi Arabia with 60 female university students (30 in flipped classroom and 30 in the control group). The flipped learning group was significantly better than the control group. Additionally, the participants who experienced flipped learning have positive attitudes towards it.

Ekmekci (2017) compared flipped and traditional faceto-face lecture-based writing classes on the basis of writing performances with 23 Turkish English Language Teaching (ELT) students in the experimental group and 20 ELT preparatory class students in the control group for fifteen weeks. The flipped classroom significantly outperformed the traditional one after the treatment process. Besides, the majority of the students in the flipped instruction group held positive attitudes towards the received instruction.

It is stated that the idea of flipped classroom does not work in every community, especially because of contextual differences (Muldrow, 2013), and to the best knowledge of the researchers of the present study, to date, there has been no available empirical study investigating the effect of flipped instruction on the quality of the Iranian EFL learners' writing quality. Consequently, this issue was explored via this experimental research.

\section{METHOD}

\section{Participants and Groupings}

The students of two branches of an EFL learning institute in Iran, who were native speakers of Persian and studying the $2^{\text {nd }}$ edition of the book Summit 1, written by Saslow and Ascher (2012), were informed that the institute would offer a 
free intensive course on argumentative essay writing. 74 students signed up. They were given the Quick Placement Test. The score of 69 students ranged from 38 to 43; the rest were outliers; thus, those 69 learners were selected as the participants and were assigned randomly to groups of 'flipped classroom' (FC), and 'traditional classroom' (TC), but 14 learners were absent for the posttest or delayed-posttest, so they were discarded, and totally, 55 students (41 females and 14 males), ranging from 21 to 36 years old, formed the participants.

\section{Design}

The study was a pretest-treatment-posttest-delayed posttest as well as a comparison-group one. There were two independent variables called 'flipped instruction' and 'traditional instruction' as well as a dependent variable named overall writing quality.

\section{Instrumentation}

Four tests were used in each group: Quick Placement Test (QPT), a pretest, a posttest, and a delayed-posttest of argumentative essay writing. Moreover, to evaluate the participants' essays, the human scoring rubric proposed by Yamamoto, Umemura, and Kawano (2018) was utilized. This rubric is attached to the Appendix in order that more information can be provided. Furthermore, the software Camtasia was utilized to provide the instructional videos for the FC group.

Moreover, As recommended by Bergmann and Sams (2012, as cited in J. Egbert et al., 2015), the book Essay Writing for English Tests by Duigu (2002) as well as a pamphlet supplemented the videos and were utilized in conjunction with the videos and other resources for out-of-class preparation. The pamphlet included chapter 9 (Outlining an Essay) of the book Academic writing: From paragraph to essay by Zemack and Rumisek (2005), and chapter 8 (Argumentative Essay) of the book 'Longman Academic Writing Series: Essays’ by Oshima and Hogue (2014).

\section{Data Collection Procedure}

It has been mentioned in the literature that not every flipped classroom looks exactly the same (Egbert, Herman, \& Lee, 2015; Hung, 2015; Muldrow, 2013). “There are yet no set guidelines for exactly what flipped instruction should look like" (J. Egbert et al., 2015, p. 3), and there can be "as many approaches to the flipped classroom as there are researchers implementing it" (Basal, 2015, p. 33); however, many researchers pursue an approach that requires the learners to watch a video or PowerPoint presentation in preparation for follow-up activities in class; thus, the pre-recoded videos or other types of pre-prepared materials must be combined with in-class effective activities (Basal, 2015; Egbert et al., 2015; Ekmekci, 2017; Muldrow, 2013) because the underlying idea of flipped classrooms is that instruction should be done both in and outside the classroom via a variety of mediums in order that the approach can "provide rich learn- ing opportunities for students with different learning styles" (Basal, 2015, p. 33). Given the mentioned issues, the following procedure was designed and implemented in the present study.

On first session, the students in both groups wrote an essay of argumentative type, which was used as the pretest. It lasted for 40 minutes. The treatment lasted for three more sessions, during two weeks, and the immediate posttest was implemented on Session 5. Two weeks after administering the posttest, the participants were called on to take the delayed-posttest. Following Bitchener's (2008) comment, the participants were not told when the delayed post-test would be administered in order to eliminate the possibility of any student studying their personal notes or reviewing the videos. The teacher-researcher did not want the students to be prepared for the test beforehand.

\section{Procedure in the traditional classroom}

The teacher, via giving lectures, taught 'Sections of the Argumentative Essay', 'Selecting and Presenting Ideas', and how to write the argumentative essays. The students were required to listen carefully. Although some exercises were done in class, because the teacher had to use most of the class time to explain the lesson, there was limited time for the writing practice itself. Therefore, the students had to do the exercises of the book or pamphlet and their writing tasks at home.

\section{Procedure in the flipped classroom}

After the students took the pretest, the teacher-researcher explained the instructional technique which would be used during the class. Then, they were provided with two instructional PowerPoint Files and a video on a DVD. For the rest of the treatment sessions, the students, at their convenience, received the pre-recorded instructional videos the teacher had already provided for them by email or download it to their memory cards of their smart phones, tablets, or laptops in class.

The whole flipped classroom was a kind of workshop in which students could ask questions about video content, evaluate their understanding, and interact with each other through hands-on activities. The students were required to watch the videos at home before coming to class. They had the possibility of reviewing the videos at their own pace and pause to take notes or review the important points. However, as Bergman and Sams (2012, as cited in Ekmekci, 2017) stated, teacher-created videos that students watch are not the vital point in flipped classrooms and the crucial point is how teachers best use in-class-time with students. Due to the fact that English was not the native language of the students in the current study, the possibilities of misunderstanding occurring due to insufficient English ability were high, so in the classroom, the students were required to lecture on what they learned from the video.

The students were also engaged in active learning by studying in groups. Group discussions and group work were done to clarify any confusion or misconceptions that may 
Table 1. Treatment period procedure in the FC group

\begin{tabular}{|c|c|c|}
\hline \multicolumn{2}{|c|}{ Treatment Period } & \multirow{2}{*}{$\begin{array}{l}\text { Procedure } \\
\text { After administering the pretest, the teacher-researcher explained the instructional technique which would } \\
\text { be used during the class. Then, the students received a DVD, carrying two instructional PowerPoint files } \\
\text { and an instructional video. The PowerPoint files were about 'Sections of the Argumentative Essay' and } \\
\text { 'Selecting and Presenting Ideas'. The video taught how to outline an essay. The students were required to } \\
\text { watch and study the materials at home before coming to class. }\end{array}$} \\
\hline Week 1 & Session 1 & \\
\hline & Session 2 & $\begin{array}{l}\text { The students lectured on what they learned from the PowerPoint files and video; they explained the points, } \\
\text { negotiate the issues, and asked their peers or teacher their questions to clarify any misunderstanding or } \\
\text { vague points. } \\
\text { Then, they received the second video holding an instruction on how to write an argumentative essay } \\
\text { of opinion-led type (i.e., whether the person agrees or disagrees with an opinion). Like the previous } \\
\text { assignment, the students were required to watch and study the information in the video at home before } \\
\text { coming to class. }\end{array}$ \\
\hline & Session 3 & $\begin{array}{l}\text { For about } 20 \text { minutes, the students could ask either the teacher or the peers their questions. Then, the } \\
\text { teacher gave the learners a new topic of the same type and asked them to work in pairs and write an essay } \\
\text { collaboratively. The allotted time for this activity was } 40 \text { minutes. Because the purpose of this activity } \\
\text { was not testing the students' writing skill, rather it was done in order for them to practice, they could refer } \\
\text { to their writing or grammar books for more information or resolving their problems. They could even } \\
\text { ask their peers in other groups their questions. Then the final } 30 \text { minute of the class was spent providing } \\
\text { teacher oral feedback on the written essays. } \\
\text { Finally, the students received the third video holding an instruction on how to write an argument-led essay } \\
\text { type (i.e., providing the person with two arguments of a topic and requiring him/her to discuss both views } \\
\text { and give their own opinion). The students' responsibility was as the previous sessions. }\end{array}$ \\
\hline \multirow[t]{2}{*}{ Week 2} & Session 4 & The same procedure as Session 3 of Week 1 was applied. \\
\hline & Session 5 & The posttest was implemented. \\
\hline
\end{tabular}

have arisen after using the videos and/or resources. These tasks provide opportunities for collaborative learning and problem-solving (Shimamoto, 2012; Straye, 2007) as students share their ideas and understand the lessons that they might otherwise be unable to achieve on their own. The teacher was there to provide help, especially the individualized one for clarifying the misunderstanding, solving problems and giving feedback when needed. Students had a chance for additional practicing and support. The teacher's presence ensured that the students would be guided and helped whenever they were confused.

As recommended by Bergmann and Sams, 2012, as cited in J. Egbert et al., (2015), two textbooks complemented the videos and were utilized in conjunction with the videos and other resources for preparation both in and out of the class.

\section{ANALYSES AND RESULTS}

\section{Inter-rater Reliability}

To assess the inter-rater reliability of the tests in the study, Cronbach alpha coefficient was utilized. Table 2 shows the results.

\section{The Normality Tests}

The assumption of normality was examined through both the graphic of histogram and the numerical way recommended by Larson-Hall (2010); the ratio of skewedness and kurtosis over their respective standard errors, as well as the Kolm-ogorov-Smirnov and the Shapiro-Wilk tests were utilized as the numerical way of assessing the normality (Field, 2013;
Larson-Hall, 2010). The only test that proved to be normal was the Quick Placement Tests in both groups, so independent samples t-test was used for it. However, the other tests of both groups did not enjoy normal distribution as indicated by histograms and the mentioned numerical tests; the outcomes of the ratio of kurtosis were not within the ranges of +/- 1.96 (Field, 2013); The found Sig. values on the Kolmogorov-Smirnov and the Shapiro-Wilk tests were.000. As a result, the relevant non-parametric tests were used to find the answers to the research questions.

\section{Ensuring the Homogeneity of the Groups}

First, an independent t-test was run to compare the mean scores of the FC and TC groups on the QPT in order to prove that both groups enjoyed the same level of general language proficiency prior to the administration of the treatments.

First, it should be noted that, the assumption of homogeneity of variances was not met (Levene's $\mathrm{F}=.01, p=.01$ $<.05$ ). That is why the second row of Table 4, "Equal variances not assumed" is reported. Based on the results displayed in Tables 3 and 4, it could be concluded that on average, there was not a significant difference between the groups at the outset of the study. FC group $(M=40.61)$; TC group $(M=40.67) . t(53)$ equaled -.15, and the $\mathrm{p}$-value for this $\mathrm{t}$ was. 87 (Sig (2-tailed) $=.87>.05)$; however, it represented a very small-sized effect (Cohen's $d=.04 ; \mathrm{r}=.02$ ).

In addition, a Mann-Whitney $U$ test was run to compare the pretests in TC and FC groups to find out whether the groups were homogeneous in their overall writing performance. The test revealed no significant difference between them (TC 
Table 2. Inter-rater reliability

\begin{tabular}{llr}
\hline Groups & Tests & Indices \\
\hline TC & Pretest & 0.78 \\
& Posttest & 0.83 \\
& Delayed-Posttest & 0.88 \\
FC & Pretest & 0.83 \\
& Posttest & 0.89 \\
& Delayed-Posttest & 0.92 \\
\hline
\end{tabular}

Table 3. Descriptive statistics QPT

\begin{tabular}{lllll}
\hline Group & N & Mean & SD & SEM \\
\hline FC & 28 & 40.61 & 1.39 & 0.264 \\
TC & 27 & 40.67 & 1.38 & 0.267 \\
\hline
\end{tabular}

Table 4. Independent t-test QPT

\begin{tabular}{|c|c|c|c|c|c|c|c|c|c|}
\hline & \multirow{3}{*}{$\begin{array}{c}\text { Levene's test } \\
\text { for equality } \\
\text { of variances }\end{array}$} & \multicolumn{8}{|c|}{ t-test for equality of means } \\
\hline & & \multirow[t]{2}{*}{ Sig. } & \multirow[t]{2}{*}{$\mathbf{t}$} & \multirow[t]{2}{*}{ df } & \multirow[t]{2}{*}{ Sig. (2-tailed) } & \multirow{2}{*}{$\begin{array}{c}\text { Mean } \\
\text { difference }\end{array}$} & \multirow{2}{*}{$\begin{array}{l}\text { Standard error } \\
\text { difference }\end{array}$} & \multicolumn{2}{|c|}{$95 \%$ confidence interval } \\
\hline & & & & & & & & Lower & Upper \\
\hline $\begin{array}{l}\text { Equal variances } \\
\text { assumed }\end{array}$ & 0.01 & 0.91 & -0.15 & 53 & 0.87 & -0.06 & 0.37 & -0.81 & 0.69 \\
\hline $\begin{array}{l}\text { Equal variances } \\
\text { not assumed }\end{array}$ & & & -0.15 & 52.95 & 0.87 & -0.06 & 0.37 & -0.81 & 0.69 \\
\hline
\end{tabular}

Group: $(M d=4.50))$, (FC Group $(M d=4.50), \mathrm{U}=362.00, z$ $=-.292, p=.77>.05$; however, it represented a very small effect $(\mathrm{r}=-.02)$ based on Cohen (1988, as cited in Pallant, 2013).

\section{Findings of the Research Questions}

First, the Mann-Whitney U Test, which was run to compare the posttests in TC and FC groups, revealed a significantly difference in the overall quality of the groups' argumentative essays (TC Group: $(M d=5.50))$, (FC Group $(M d=6.75)$, $\mathrm{U}=60.50, z=-5.60, p=.000, \mathrm{r}=-.75$. The median scores showed that the FC outperformed the TC and the found effect size was large, based on Cohen (1988, as cited in Pallant, 2013).

Then, another Mann-Whitney U Test was run to compare the delayed-posttests in TC and FC groups to find out whether or not the found difference between groups vary over time. The test indicated that the two groups were still significantly different and the FC was still superior in their overall quality of their argumentative essays (TC Group: $(M d=5.50))$, (FC Group $(M d=6.50), \mathrm{U}=71.50, z=-5.46, p=.000, \mathrm{r}=-.73$. The median scores also showed no change. A large effect size was also found.

Finally, because the FC was found to be superior in their overall quality of their essays, a Wilcoxon Signed Rank Test was run to compare the posttest and delayed-posttest of this group to reveal whether or not there would be any significant change in it in the long term. The test showed no significant difference: $z=-1.63, p=.10$; the median scores indicated no change $(M d=6.00)$; however, the calculation of the effect size represented below medium effect size $(r=-.22)$.

\section{DISCUSSION AND CONCLUSION}

The findings of this study prove that flipped writing class improves students' writing quality more than the traditional lecture-based writing instruction, so employing flipped learning in writing classes can be considered as an effective way of instruction for improving writing skills of EFL students. The findings corroborate the previous relevant studies considering the effect of flipped writing classrooms on the EFL learners' writing proficiency (Afrilyasanti, Cahyono, \& Astuti, 2016; Ahmed, 2016; Ekmekci, 2017; Farah, 2014; Leis, Tohei, \& Cooke, 2015). The results can be attributed to the following points:

The findings could be interpreted as the benefits of incorporating different techniques in teaching, which is in fact a form of blended learning and a set of class tasks that are differentiated depending on students' personal and various abilities (Ahmed, 2016). The findings supports the belief that if the learners' differences, such as their different needs and learning styles, are satisfied by the utilized educational technique in the classroom, such as the video screencasting in the present study, beneficial effects will be produced (Afrilyasanti, Cahyono, \& Astuti, 2016; Cohen, 2012; Dörnyei, 2005; Mayer \& Moreno, 2003). 
Moreover, what has been found corroborates the effectiveness of active learning and actively engaging the learners in their learning, so that they would not be the passive recipients of knowledge, rather they undertake responsibility for their learning (Baepler, Walker, \& Driessen, 2014; Basal, 2015; Davies, Dean, \& Ball, 2013; Muldrow, 2013; O’Flaherty \& Phillips, 2015).

Additionally, as the students had this opportunity to write collaboratively, this activity could have positive effects on the participants ability to write their essays, and this can be considered as consistent with the findings of previous studies (See, e.g. Ajideh, Leitner, \& Yazdi-Amirkhiz, 2016; Elola \& Oskoz, 2010; Shehadeh, 2011; Storch, 2005; Storch \& Wigglesworth, 2007) and the sociocultural perspective in L2 instruction, which requires the learners to seek cooperation and assistance from different people and resources (Cumming, 2001). It has been stated that collaboration makes learners think about their language-related problems when they are engaged in their writing tasks (Swain, 2000); therefore, it is highly recommended that learners "be encouraged to participate in activities which foster interaction and co-construction of knowledge" (Storch, 2005, p. 154).

Furthermore, the findings prove the effectiveness of teacher-learner interaction and face-to-face negotiation to reduce the misunderstandings, as is in line with Long's (1996) Interaction Hypothesis and Vygotsky's emphasis on the importance of meaningful social interactions between novice learners and more experienced others (Nyikos \& Hashimoto, 1997; O’Donoghue \& Clarke, 2010); Vygosky believed that such interaction will support learning because cognitive functions originate in social interaction and that learning "is the process by which learners are integrated into a knowledge community" (Woo \& Reeves, 2007, p. 18); such interaction is highly recommended by several scholars (e.g. Han \& Hyland, 2015; Hyland, 2009; Lee, 2013; Nassaji, 2011; Nicol, 2010; Pica, 1994; Williams \& Severino, 2004) because it is assumed to be essential for the learner's cognitive development to occur and progress, "which extend his or her knowledge of the task at hand from a lower level of understanding to a higher order of thinking through, with the assistance of more experienced social partners" (Lin \& Yang, 2011, p. 4). Therefore, through the process of negotiation, the participants in the FC were able to understand their own strengths and weaknesses; they could also learn what to "do to close the gaps (i.e. improve the weaknesses) in their writing" (Lee, 2014, p. 204).

In conclusion, in this study, through the flipped instruction, both cognitive apprenticeship and scaffolding occurred; like what Nyikos and Hashimoto (1997) explained, the students were engaged in reflective thinking. The responsibility for learning was mainly on the learner, but the teacher, also as the more knowledgeable person, had the responsibility of offering the learner support to facilitate the process of learning because as Benko (2012) stated, scaffolding is essential for tasks which are beyond students' independent language abilities. Moreover, the different functions of interactional modifications, such as providing a condition for the learners to receive comprehensible input, produce modified output, and notice the gaps in their knowledge could help them restructure their interlanguages (Mackey, 2012).

\section{DELIMITATION OF THIS STUDY AND SUGGESTIONS FOR FURTHER RESEARCH}

As the concluding remarks, two points need to be mentioned:

First, even though the flipped instruction was proved effective in this study, we cannot generalize from this sample because the participating students in the current study were at the upper-intermediate level of English proficiency, and the flipped instruction may yield different results if it is conducted in classes with lower-proficiency-level students.

Next, a qualitative study is essential to investigate the students' attitudes and expectations towards the purpose and value of the FC with the aims of first, exploring their attitudinal engagement, which was recommended by (Ellis, 2010), and second, finding out some information about their individual differences via analyzing their statements in order to understand how they can be helped to do the writing task better (Hyland, 2009).

\section{REFERENCES}

Afrilyasanti, R., Cahyono, B. Y., \& Astuti, U. P. (2016). Effect of flipped classroom model on Indonesian EFL students' writing ability across and individual differences in learning. International Journal of English Language and Linguistics Research, 4(5), 65-81. Retrieved from http://www.eajournals.org/wp-content/ uploads/Effect-Of-Flipped-Classroom-Model-on-Indonesian-EFL-Students'-Writing-Ability-Across-and-Individual-Differences-in-Learning.pdf

Ahmed, M. A. E. A. S. (2016). The effect of a flipping classroom on writing skill in English as a foreign language and students' attitude towards flipping. US-China Foreign Language, 14(2), 98-114. https://doi. org/10.17265/1539-8080/2016.02.003

Ajideh, P., Leitner, G., \& Yazdi-Amirkhiz, S. Y. (2016). The influence of collaboration on individual writing quality: The case of Iranian vs. Malaysian college students. Journal of English Language Teaching and Learning, 17, 1-24. Retrieved from http://elt.tabrizu.ac.ir/article_4958_2d1abea04fc764847e84f5e86b902382.pdf

Baepler, P., Walker, J. D., \& Driessen, M. (2014). It's not about seat time: Blending, flipping, and efficiency in active learning classrooms. Computers \& Education, 78, 227-236. https://doi.org/10.1016/j.compedu.2014.06.006

Basal, A. (2015). The implementation of a flipped classroom in foreign language teaching. Turkish Online Journal of Distance Education, 16(4), 28-37. https://doi. org/10.17718/tojde. 72185

Benko, S. L. (2012). Scaffolding: An ongoing process to support adolescent writing development. Journal of Adolescent \& Adult Literacy, 56(4), 291-300. https://doi. org/10.1002/JAAL.00142

Bishop, J. L., \& Verleger, M. A. (2013). The flipped classroom: A survey of the research. In $120^{\text {th }}$ ASEE Annu- 
al Conference \& Exposition in Atlanta. Retrieved from www.asee.org/file_server/papers/attachment/ file/0003/3259/6219.pdf

Bitchener, J. (2008). Evidence in support of written corrective feedback. Journal of Second Language Writing, 17(2), 102-118. https://doi.org/10.1016/j.jslw.2007.11.004

Bonnell, C. C., \& Eison, J. A. (1991). Active learning: Creating excitement in the classroom. Washington, DC: George Washington University Press.

Cohen, A. D. (2012). Strategies: The interface of styles, strategies, and motivation on tasks. In S. Mercer, R. Stephen, \& M. Williams (Eds.), Psychology for language learning: Insights from research, theory and practice (pp. 136-150). Basingstoke, England: Palgrave Macmillan.

Cumming, A. (2001). Learning to write in a second language: Two decades of research. IJES, International Journal of English Studies, 1(2), 1-23. Retrieved from https:// tspace.library.utoronto.ca/bitstream/1807/32148/1/ Learning.Research.pdf

Danker, B. (2015). Using flipped classroom approach to explore deep learning in large classrooms. The IAFOR Journal of Education, 3(1), 171-186. Retrieved from http://files.eric.ed.gov/fulltext/EJ1100618.pdf

Davies, R. S., Dean, D. L., \& Ball, N. (2013). Flipping the classroom and instructional technology integration in a college-level information systems spreadsheet course. Educational Technology Research and Development, 61(4), 563-580. https://doi.org/10.1007/s11423-0139305-6

Dörnyei, Z. (2005). The psychology of the language learner: Individual differences in second language acquisition. Mahwah, NJ: Lawrence Erlbaum.

Duigu, G. (2002). Essay writing for English tests. Cammeray NSW: Academic English Press.

Egbert, J., Herman, D., \& Lee, H. (2015). Flipped instruction in English language teacher education: A design-based study in a complex, open-ended learning environment. TESL-EJ, 19(2), 1-23. Retrieved from http://files.eric. ed.gov/fulltext/EJ1074707.pdf

Ekmekci, E. (2017). The flipped writing classroom in Turkish EFL context: A comparative study on a new model. Turkish Online Journal Of Distance Education (Tojde), 18(2), 151-167. https://doi.org/10.17718/tojde.306566

Ellis, R. (2010). EPILOGUE: A framework for investigating oral and written corrective feedback. Studies in Second Language Acquisition, 32(2), 335-349. https://doi. org/10.1017/S0272263109990544

Elola, I., \& Oskoz, A. (2010). Collaborative writing: Fostering foreign language and writing conventions development. Language Learning \& Technology, 14(3), 51-71. Retrieved from 1lt.msu.edu/issues/october2010/ elolaoskoz.pdf

Farah, M. (2014). The impact of using flipped classroom instruction on the writing performance of twelfth grade female Emirati students in the applied technology high school (ATHS). (Master's thesis). The British University in Dubai (BUiD). Retrieved from https://bspace.buid. ac.ae/bitstream/1234/676/1/120088.pdf

Field, A. (2013). Discovering statistics using SPSS ( $4^{\text {th }}$ ed.). London: Sage.

Han, Y., \& Hyland, F. (2015). Exploring learner engagement with written corrective feedback in a Chinese tertiary EFL classroom. Journal of Second Language Writing, 30, 31-44. https://doi.org/10.1016/j.jslw.2015.08.002

Hayes, J. R. (1996). A new framework for understanding cognition and affect in writing. In C. M. Levy \& S. Ransdell (Eds.), The science of writing: Theories, methods, individual differences and applications (pp. 1-27). Hillsdale, NJ: Lawrence Erlbaum Associates.

Hung, H.-T. (2015). Flipping the classroom for English language learners to foster active learning. Computer Assisted Language Learning, 28(1), 81-96. https://doi.org $/ 10.1080 / 09588221.2014 .967701$

Hyland, K. (2009). Teaching and researching writing ( $2^{\text {nd }}$ ed.). Harlow, UK: Pearson Education Limited.

Johnson, L. W., \& Renner, J. D. (2012). Effect of the flipped classroom model on a secondary computer applications course: Student and teacher perceptions, questions and student achievement. (Doctoral dissertation). University of Louisville. Louisville, Kentucky. Retrieved from https://s3.amazonaws.com/academia.edu.documents/38862495/ Flipped_Classroom.pdf?AWSAccessKeyId=AKIAIWOWYYGZ2Y53UL3A\&Expires=1510424082\&Signature $=$ X O V P m 18 u XfH Mh V MnN 3 n 9 e $3 \mathrm{~N}$ $95 \mathrm{cU} \% 3 \mathrm{D} \&$ response-content-disposition $=$ inline $\% 3 \mathrm{~B}$ filename\%3DEffects_of_Flipped_Classroom.p

Katayama, A. (2007). Japanese EFL students' preferences toward correction of classroom oral errors. Asian EFL Journal, 9(4). Retrieved from http://www.asian-efl-journal.com/Dec_2007_ak.php

Kellogg, R. T. (1996). A model of working memory in writing. In C. M. Levy \& S. Ransdell (Eds.), The science of writing: Theories, methods, individual differences and applications (pp. 57-71). Mahwah, NJ: Lawrence Erlbaum Associates.

Kormos, J. (2012). The role of individual differences in L2 writing. Journal of Second Language Writing, 21(4), 390-403. https://doi.org/10.1016/j.jslw.2012.09.003

Larson-Hall, J. (2010). A guide to doing statistics in second language research using SPSS. New York, NY: Routledge.

Lee, I. (2013). Research into practice: Written corrective feedback. Language Teaching, 46(1), 108-119. https:// doi.org/10.1017/S0261444812000390

Lee, I. (2014). Revisiting teacher feedback in EFL writing from sociocultural perspectives. TESOL Quarterly, 48(1), 201-213. https://doi.org/10.1002/tesq.153

Leis, A., Tohei, A. A., \& Cooke, S. (2015). The effects of flipped classrooms on English composition writing in an EFL environment. International Journal of Computer-Assisted Language Learning and Teaching (IJCALLT), 5(4), 37-51. https://doi.org/10.4018/IJCALLT.2015100103

Lin, W. C., \& Yang, S. C. (2011). Exploring students' perceptions of integrating Wiki technology and peer feedback 
into English writing courses. English Teaching: Practice and Critique, 10(2), 88-103. Retrieved from http://files. eric.ed.gov/fulltext/EJ944900.pdf

Long, M. H. (1996). The role of the linguistic environment in second language acquisition. In W. Ritchie \& T. Bhatia (Eds.). Handbook of second language acquisition (pp. 438-468). San Diego, CA: Academic Press.

Mackey, A. (2012). Input, interaction, and corrective feedback in L2 learning. Oxford, UK: Oxford University Press.

Mayer, R. E., \& Moreno, R. (2003). Nine ways to reduce cognitive load in multimedia learning. Educational Psychologist, 38(1), 43-52. https://doi.org/10.1207/ S15326985EP3801 6

Meyers, C., \& Jones, T. B. (1993). Promoting active learning: Strategies for the college classroom. San Francisco, CA: Jossey-Bass.

Muldrow, K. (2013). A new approach to language instruction: Flipping the classroom. The Language Educator, (November), 28-31. Retrieved from https://www.actfl. org/sites/default/files/pdfs/TLE_pdf/TLE_Nov13_Article.pdf

Nassaji, H. (2011). Correcting students' written grammatical errors: The effects of negotiated versus nonnegotiated feedback. Studies in Second Language Learning and Teaching, 1(3), 315-334. https://doi.org/10.14746/ ssllt.2011.1.3.2

Nicol, D. (2010). From monologue to dialogue: Improving written feedback processes in mass higher education. Assessment \& Evaluation in Higher Education, 35(5), 501-517. https://doi.org/10.1080/02602931003786559

Nyikos, M., \& Hashimoto, R. (1997). Constructivist theory applied to collaborative learning in teacher education: In search of ZPD. The Modern Language Journal, 81(4), 506-517. https://doi.org/10.1111/j.1540-4781.1997. tb05518.x

O’Donoghue, T., \& Clarke, S. (2010). Leading learning. Process, themes and issues in international contexts. Abingdon, Oxon: Routledge.

O'Flaherty, J., \& Phillips, C. (2015). The use of flipped classrooms in higher education: A scoping review. The Internet and Higher Education, 25, 85-95. https://doi org/10.1016/j.iheduc.2015.02.002

Oshima, A., \& Hogue, A. (2014). Longman academic writing series: Essays ( $5^{\text {th }}$ ed.). White Plains, NY: Pearson Education.

Pallant, J. (2013). SPSS survival manual: A step by step guide to data analysis using IBM SPSS ( $5^{\text {th }}$ ed.). Berkshire, England: Open University Press.

Pica, T. (1994). Research on negotiation: What does it reveal about second-language learning conditions, processes, and outcomes? Language Learning, 44(3), 493-527. https://doi.org/10.1111/j.1467-1770.1994.tb01115.x

Richards, J. C., \& Renandya, A. W. (2002). Teaching writing. In J. C. Richards \& A. W. Renandya (Eds.), Methodology in language teaching: An anthology of current practice (pp. 303-305). Cambridge, UK: Cambridge University Press.
Richards, J. C., \& Rodgers, T. S. (2014). Approaches and methods in language teaching ( $3^{\text {rd }}$ ed.). Cambridge, UK: Cambridge University Press.

Roehl, A., Reddy, S. L., \& Shannon, G. J. (2013). The flipped classroom: An opportunity to engage millennial students through active learning strategies. Journal of Family and Consumer Sciences, 105(2), 44-49. Retrieved from https://pdfs.semanticscholar.org/daa3/b94cdc7b52b3381a7c7e21022a7a8c005f84.pdf

Saslow, J., \& Ascher, A. (2012). Summit 1 ( $2^{\text {nd }}$ ed.). New York, NY: Pearson Education.

Shehadeh, A. (2011). Effects and student perceptions of collaborative writing in L2. Journal of Second Language Writing, 20(4), 286-305. https://doi.org/10.1016/j. jslw.2011.05.010

Shimamoto, D. (2012). Implementing a flipped classroom: An instructional module. In The Technology, Colleges, and Community (TCC) Worldwide Online Conference. Retrieved from https://scholarspace.manoa.hawaii.edu/ bitstream/10125/22527/1/ETEC690-FinalPaper.pdf

Storch, N. (2005). Collaborative writing: Product, process, and students' reflections. Journal of Second Language Writing, 14(3), 153-173. https://doi.org/10.1016/j. jslw.2005.05.002

Storch, N., \& Wigglesworth, G. (2007). Writing tasks: The effects of collaboration. In M. D. P. G. Mayo (Ed.), Investigating tasks in formal language learning (pp. 157177). London, UK.: Multilingual Matters.

Straye, J. F. (2007). The effects of the classroom flip on the learning environment: A comparison of learning activity in a traditional classroom and a flip classroom that used an intelligent tutoring system. (Doctoral dissertation). The Ohio State University. Retrieved from https://etd.ohiolink.edu/!etd.send_file? accession $=0-$ su1189523914\&disposition=inline

Swain, M. (2000). The output hypothesis and beyond: Mediating acquisition through collaborative dialogue. In J. P. Lantolf (Ed.), Sociocultural theory and second language learning (pp. 97-114). Oxford, UK: Oxford University Press.

Tucker, B. (2012). The flipped classroom: Online instruction at home frees class time for learning. Education Next, 12(1), 82-83. Retrieved from http://www. msuedtechsandbox.com/MAETELy2-2015/wp-content/uploads/2015/07/the_flipped_classroom_article_2.pdf

Warschauer, M. (2005). Sociocultural perspectives on CALL. In J. L. Egbert \& G. M. Petrie (Eds.), CALL research perspectives (pp. 41-52). Mahwah, New Jersey: Lawrence Erlbaum Associates, Inc.

Warschauer, M., Turbee, L., \& Roberts, B. (1996). Computer learning networks and student empowerment. System, 24(1), 1-14. https://doi.org/10.1016/0346251X(95)00049-P

Williams, J., \& Severino, C. (2004). The writing center and second language writers. Journal of Second Language Writing, 13(3), 165-172. https://doi.org/10.1016/j. jslw.2004.04.010 
Woo, Y., \& Reeves, T. C. (2007). Meaningful interaction in web-based learning: A social constructivist interpretation. Internet and Higher Education, 10(1), 15-25. https://doi.org/10.1016/j. iheduc.2006.10.005

Yamamoto, M., Umemura, N., \& Kawano, H. (2018). Automated essay scoring system based on rubric. In $\mathrm{R}$.
Lee (Ed.), Applied computing \& information technology. ACIT 2017. Studies in Computational Intelligence, vol 727 (pp. 177-190). Springer, Cham. https://doi. org/10.1007/978-3-319-64051-8_11

Zemack, D. E., \& Rumisek, L. A. (2005). Academic writing: From paragraph to essay. Oxford, UK: Macmillan Education.

\section{APPENDIX}

\begin{tabular}{|c|c|c|c|c|c|}
\hline \multicolumn{6}{|c|}{ The Rubric for Scoring the essays } \\
\hline \multirow{2}{*}{$\begin{array}{l}\text { Evaluation } \\
\text { viewpoint }\end{array}$} & \multicolumn{5}{|c|}{ Achievement level and scoring } \\
\hline & D (0-1) & $C(2-3)$ & B (4-5) & $A(6-7)$ & $A+(8-9)$ \\
\hline $\begin{array}{l}\text { [Content] } \\
\text { Understanding } \\
\text { of the assigned } \\
\text { tasks and validity } \\
\text { of contents }\end{array}$ & $\begin{array}{l}\text { Misunderstanding } \\
\text { the assigned task, } \\
\text { or the contents are } \\
\text { not related to the } \\
\text { topic at all }\end{array}$ & $\begin{array}{l}\text { Understanding } \\
\text { the assigned } \\
\text { task, but } \\
\text { includes some } \\
\text { errors }\end{array}$ & $\begin{array}{l}\text { Understanding } \\
\text { the assigned } \\
\text { task, but the } \\
\text { contents are } \\
\text { insufficient }\end{array}$ & $\begin{array}{l}\text { Understanding } \\
\text { the assigned } \\
\text { task, but has } \\
\text { some points to } \\
\text { improve }\end{array}$ & $\begin{array}{l}\text { Appropriate contents } \\
\text { with relevant terms. } \\
\text { No need for } \\
\text { improvement }\end{array}$ \\
\hline $\begin{array}{l}\text { [Structure] } \\
\text { Logical } \\
\text { development }\end{array}$ & $\begin{array}{l}\text { No structure or } \\
\text { theoretical } \\
\text { development }\end{array}$ & $\begin{array}{l}\text { There is a } \\
\text { contradiction in } \\
\text { the development } \\
\text { of the theory }\end{array}$ & $\begin{array}{l}\text { Although } \\
\text { developing } \\
\text { theory in order, } \\
\text { there are some } \\
\text { points to be } \\
\text { improved }\end{array}$ & $\begin{array}{l}\text { Although } \\
\text { developing } \\
\text { theory in order, } \\
\text { the theory is not } \\
\text { compelling }\end{array}$ & $\begin{array}{l}\text { The theory is } \\
\text { compelling and } \\
\text { conveying the } \\
\text { writer's } \\
\text { understanding }\end{array}$ \\
\hline $\begin{array}{l}\text { [Evidence] } \\
\text { Validity of } \\
\text { sources and } \\
\text { evidence }\end{array}$ & $\begin{array}{l}\text { It does not show } \\
\text { evidence }\end{array}$ & $\begin{array}{l}\text { Demonstrates } \\
\text { an attempt to } \\
\text { support ideas }\end{array}$ & $\begin{array}{l}\text { The sources to } \\
\text { be referenced } \\
\text { are inappropriate } \\
\text { or unreliable }\end{array}$ & $\begin{array}{l}\text { Uses relevant } \\
\text { and reliable } \\
\text { sources, but the } \\
\text { way of } \\
\text { reference is not } \\
\text { suitable }\end{array}$ & $\begin{array}{l}\text { Demonstrates } \\
\text { the skillful use } \\
\text { of high-quality } \\
\text { and relevant } \\
\text { sources }\end{array}$ \\
\hline $\begin{array}{l}\text { [Style] } \\
\text { Proper usage } \\
\text { of grammar } \\
\text { and elaboration } \\
\text { of sentences }\end{array}$ & $\begin{array}{l}\text { There are some } \\
\text { Grammatical errors. } \\
\text { Many corrections } \\
\text { required }\end{array}$ & $\begin{array}{l}\text { Not following } \\
\text { the rules. Some } \\
\text { corrections } \\
\text { required }\end{array}$ & $\begin{array}{l}\text { Almost follow } \\
\text { the rules. A few } \\
\text { corrections } \\
\text { required }\end{array}$ & $\begin{array}{l}\text { Although } \\
\text { error-free, some } \\
\text { improvement } \\
\text { will be better }\end{array}$ & $\begin{array}{l}\text { Virtually error-free and } \\
\text { well elaborated. } \\
\text { No point to } \\
\text { improve }\end{array}$ \\
\hline $\begin{array}{l}\text { [Skill] } \\
\text { Readability } \\
\text { and writing } \\
\text { skill }\end{array}$ & $\begin{array}{l}\text { The sentences are } \\
\text { hard to read. } \\
\text { Writing skills are } \\
\text { missing }\end{array}$ & $\begin{array}{l}\text { There are } \\
\text { several points } \\
\text { to be improved, } \\
\text { such as the } \\
\text { length of } \\
\text { sentences }\end{array}$ & $\begin{array}{l}\text { Although } \\
\text { sentences can be } \\
\text { read generally, } \\
\text { some } \\
\text { improvement } \\
\text { will be better }\end{array}$ & $\begin{array}{l}\text { Easy to read. } \\
\text { Rich in } \\
\text { vocabulary }\end{array}$ & $\begin{array}{l}\text { Easy to read. } \\
\text { Skillfully } \\
\text { Communicates } \\
\text { meaning to readers. } \\
\text { Rich in } \\
\text { vocabulary }\end{array}$ \\
\hline
\end{tabular}

